\title{
KONFLIK SOSIAL DALAM NOVEL TENTANG KAMU KARYA TERE LIYE: TINJAUAN SOSIOLOGI SASTRA
}

\author{
Siti Nurchanifah \\ (Pendidikan Bahasa dan Sastra Indonesia, Fakultas Keguruan dan Ilmu Pendidikan, \\ Universitas PGRI Adi Buana Surabaya) \\ sitinurchanifah@gmail.com \\ Luluk Isani Kulup \\ (Pendidikan Bahasa dan Sastra Indonesia, Fakultas Keguruan dan Ilmu Pendidikan, \\ Universitas PGRI Adi Buana Surabaya) \\ kulupluluk@gmail.com
}

\begin{abstract}
Humans as social beings must have experienced a contradiction or dispute. In the daily life of many people who experience social conflicts, both in real life and in literary works such as theater, film, novel, and so on. This research is motivated by the number of social conflicts in novel characters are no exception to the novel About You. The approach used in this research is the sociology of literature. Sociology of literature is an approach in analyzing literary works that talk about the relationship between the author's life with his social life. This study aims to describe social conflict in Tere Liye's novel About You. The research method used is descriptive qualitative research. The data in this study is data that tangible words, phrases, and sentences contained in Tere Liye's novel About You. The data obtained by using library techniques, refer to, and record. Data were analyzed using descriptive method. After the data were collected and analyzed, there were fifty-five data from the six social conflicts of Soekanto. The social conflict consists of poverty which includes property poverty, moral poverty, and religious poverty, crimes, family disorganization, the problems of young people in modern society, fights, and violations of community norms in the form of child prostitution and delinquency.
\end{abstract}

Keywords: Social Conflict, Novel, Sociology of Literature.

\section{PENDAHULUAN}

Sastra adalah suatu kegiatan kreatif, sebuah karya seni. Sastra juga cabang ilmu pengetahuan. Studi sastra memiliki metode-metode yang ilmiah walaupun tidak selalu sama dengan metode ilmu-ilmu alam. Ilmuilmu alam mempelajari fakta-fakta yang berulang, sedangkan sejarah mengkaji fakta-fakta yang silih berganti.

Karya sastra merupakan media untuk mengungkapkan pikiranpikiran pengarang. Karya sastra bersifat imajinatif, estetik dan menyenangkan pembaca. Karya sastra diciptakan oleh sastrawan untuk mengungkapkan persoalan tentang kehidupan. Karya sastra tercipta karena adanya pengalaman batin pengarang berupa peristiwa atau problem dunia yang menarik sehingga muncul gagasan imajinasi yang dituangkan dalam bentuk tulisan. Karya sastra akan menyumbangkan tata nilai figur dan tatanan tuntutan masyarakat. Hal ini merupakan ikatan timbal balik antara karya sastra dengan masyarakat. Walaupun karya sastra tersebut berupa fiksi namun pada kenyataannya, sastra juga mampu memberikan manfaat yang berupa nilai-nilai moral bagi pembacanya. 
Ada berbagai bentuk karya sastra, salah satunya yaitu novel. Novel adalah karangan prosa yang lebih panjang dari cerita pendek dan menceritakan kehidupan seseorang dengan lebih mendalam dengan menggunakan bahasa sehari-hari serta banyak membahas aspek kehidupan manusia. Hal ini mengacu pada pendapat Santoso dan Wahyuningtyas (2010:46), yang menjelaskan, "Kata novel berasal dari bahasa latin novellas, yang terbentuk dari kata novus yang berarti baru atau new dalam bahasa Inggris. Novel juga diartikan sebagai suatu karangan atau karya sastra yang lebih pendek daripada roman, tetapi jauh lebih panjang daripada cerita pendek, yang isinya hanya mengungkapkan suatu kejadian yang penting, menarik dari kehidupan seseorang (dari suatu episode kehidupan seseorang) secara singkat dan yang pokok-pokok saja.

Novel Tentang Кати karya Tere Liye menarik untuk diteliti. Alasan pertama mengambil novel Tentang Kamu karya Tere Liye digunakan sebagai penelitian karena novel ini memaparkan sebuah kisah perjuangan seorang perempuan yang menghadapi kehidupan yang penuh liku-liku. Alasan kedua, makna yang terkandung di dalam novel sangat erat hubungannya dengan kehidupan sehari-hari, yakni konflik sosial dalam masyarakat. Alasan ketiga, novel ini menyajikan berbagai konflik sosial.

Konflik sosial menurut Soekanto adalah suatu proses sosial di mana individu atau kelompok berusaha untuk memenuhi tujuannya dengan jalan menentang pihak lawan yang disertai dengan ancaman atau kekerasan. Ketertarikan terhadap konflik sosial dikarenakan konflik sosial sangat erat hubungannya dengan lingkungan sekitar, sehingga banyak sekali hal-hal yang perlu diperhatikan dalam berbagai konflik sosial, mulai dari sebab akibat konflik sosial itu terjadi dan bagaimana bentuk pemecahan terhadap konflik sosial tersebut. Konflik sosial ini diangkat dan perlu dikaji agar dapat memberikan pembelajaran bagi pembaca. Dengan memahami konflik sosial yang ada dalam novel Tentang Kamu karya Tere Liye pembaca mampu mengetahui macam-macam konflik sosial yang ada dalam kehidupan.

Tinjauan yang digunakan yakni tinjauan sosiologi sastra. Menurut Saraswati (2003:1), sosiologi sastra merupakan suatu ilmu interdisipliner (lintas disiplin), antara sosiologi dan ilmu sastra. Selanjutnya, menurut Ratna (2003:1), sosiologi membicarakan tentang asal-usul, pertumbuhan masyarakat, ilmu pengetahuan yang mempelajari tentang hubungan antara manusia dalam masyarakat, mempunyai sifat yang umum, rasional, dan empiris. Sosiologi meneliti hubungan individu dengan kelompok dan budayawan sebagai unsur yang bersama-sama membentuk kenyataan hidup masyarakat dan kenyataan sosial. Tinjauan ini digunakan dalam penelitian karena sosiologi sastra mencakup tentang semua ilmu sosial, salah satunya adalah konflik sosial.

Dari paparan di atas, penelitian ini ingin menjawab permasalahan, Bagaimana konflik sosial dalam novel Tentang Kamu karya Tere Liye. Hasil dari penelitian ini diharapkan dapat bermanfaat dalam memberikan kontribusi perkembangan ilmu sastra dan menjadi saran pembelajaran dan pengetahuan selanjutnya.

Dalam artikel ini, Konsep
konflik muncul pada awal


perkembangan industri di negaranegara industri di mana terjadi perubahan sosial yang mengarah pada perbedaan kepentingan pemilik modal dengan buruh atau pekerja (Jurnal Bastra, Vol. 1 No. 1, pp. 3-4, 2016). Pada bagian ini, kita akan lebih berkonsentrasi pada konflik sosial. Menurut Soerjono Soekanto, konflik sosial adalah suatu proses sosial di mana individu atau kelompok berusaha untuk memenuhi tujuannya dengan jalan menentang pihak lawan yang disertai dengan ancaman atau kekerasan.

Dalam teori konflik sosial, Soekanto (2014:319-345) menyatakan konflik sosial yang ada pada umumnya dihadapi masyarakat antara lain: kemiskinan, kejahatan, disorganisasi keluarga, masalah generasi muda dalam masyarakat modern, peperangan, pelanggaran terhadap norma-norma masyarakat, masalah kependudukan, masalah lingkungan hidup, dan birokrasi. Sehubungan dengan masalah sosial tersebut, sosiologi tidaklah bertujuan untuk membentuk manusia yang bijaksana dan selalu baik dalam tindakannya.

Dari uraian di atas dapat disimpulkan bahwa konflik sosial merupakan suatu pertentangan atau percekcokan yang dilakukan oleh individu atau kelompok dengan tujuan untuk memperoleh status, kekuasaan, dan mempunyai keinginan untuk menghancurkan pihak lain.

\section{METODE PENELITIAN}

Metode yang digunakan dalam penelitian ini adalahdeskriptif. Metode ini dilakukandengan cara mendeskripsikan fakta-fakta yang kemudian disertai dengan analisis (Ratna, 2006:53). Pendekatan yang digunakanadalahpendekatankualitatif.
Data dalam penelitian ini adalah data yang berwujud kata-kata, ungkapan, kalimat yang terdapat dalam novel Tentang Kamu karya Tere Liye, sedangkan sumber data dalam penelitian ini adalah sumber data primer dan sumber data sekunder. Sumber data primer dalam penelitian ini adalah novel Tentang Кати karya Tere Liye yang diterbitkan pada Oktober oleh Republika Penerbit dengan tebal halaman 524. Sumber data sekunder dalam penelitian ini adalah skripsi, jurnal, dan artikel dari internet yang relevan dengan penelitian ini. Pengumpulan data dalam penelitian ini adalah dengan menggunakan teknik pustaka, simak, dan catat. Analisis data dalam penelitian ini adalah deskriptif. Metode deskriptif analisis dilakukan dengan cara mendeskripsikan faktafakta yang kemudian disertai dengan analisis (Ratna, 2006:53). Ada beberapa langkah analisis dalam penelitian ini yakni, mengelompokkan data-data yang sejenis sesuai dengan konflik sosial yang terdapat dalam novel Tentang Kати karya Tere Liye, menyajikan data dalam bentuk deskripsi, membuat pemaknaan mengenai kemiskinan, kejahatan, disorganisasi, masalah generasi muda dalam masyarakat modern, peperangan, dan pelanggaran terhadap norma-norma masyarakat yang terdapat dalam novel Tentang Kamu karya Tere Liye, dan membuat kesimpulan terkait dengan konflik sosial yang terdapat dalam novel Tentang Кати karya Tere Liye.

\section{HASIL PEMBAHASAN}

Konflik sosial dalam novel tentang kamu karya tere liye dapat dilihat dari berbagai permasalahan yang kerap terjadi di masyarakat. 
Dalam novel Tentang Кати karya Tere Liye ditemukan adanya konflik sosial antara lain: (1) kemiskinan yang meliputi kemiskinan harta, kemiskinan moral, dan kemiskinan agama, (2) kejahatan yang berupa penindasan, penganiayaan, dan pembunuhan, (3) disorganisasi keluarga yang berbentuk krisis keluarga (kepala keluarga meninggalkan rumah tangga karena meninggal dunia dan peperangan), (4) masalah generasi muda dalam masyarakat modern, (5) peperangan yang berupa perkelahian, dan (6) pelanggaran terhadap norma-norma masyarakat yang berupa pelacuran dan delinkuensi anak-anak (pencurian, penganiyaan, pelanggaran susila, penggunaan obat-obatan, dan alkoholisme).

\section{(1) Kemiskinan}

Kemiskinan dianggap sebagai masalah sosial, apabila perbedaan kedudukan ekonomis para warga masyarakat ditentukan secara tegas. Dalam novel Tentang Кати terjadi kemiskinan yang meliputi kemiskinan harta, kemiskinan moral, dan kemiskinan agama dapat dilihat pada kutipan-kutipan sebagai berikut.

a. Kemiskinan Harta

Dalam novel Tentang Kamu karya Tere Liye, ibu Sri Ningsih mengalami kekurangan. Semua harta bendanya diinvestasikan kepada orang lain. Hal ini dilakukan agar kekayaannya tidak jatuh kepada orang jahat. Oleh karena itu, Sri Ningsih rela meninggalkan semua hartanya dan dia ingin hidup sejahtera di Panti Jompo.

"Kami tidak tahu sama sekali jika ibu Sri Ningsih baru saja melakukan perjalanan ratusan kilometer dari London sepanjang malam. Dia.... Dia tidak punya sepeser uang pun, menumpang dari satu mobil ke mobil lain. Termasuk saat menyeberangi Selat Inggris, dia menumpang perahu nelayan, karena ferry tidak mau menaikkan penumpang tanpa tiket. Tiba di daratan Perancis, dia kembali menumpang mobil demi mobil, hingga akhirnya tiba di pinggiran Kota Paris" (TK/1/34/Kms).

Pada data di atas diketahui bahwa kalimat yang digarisbawahi menjelaskan terjadi konflik sosial yang berupa kemiskinan harta yang tertuju pada Sri Ningsih. Sebelum ke panti jompo, Sri Ningsih adalah seorang pengusaha sukses yang terkaya di seluruh dunia. Dia adalah wanita yang pintar dan hebat. Namun, banyak lika-liku yang beliau alami. Tanpa diketahui oleh semua orang, dia menginvestasikan perusahaan kepada anak angkatnya dan memilih untuk meninggalkan semua itu tanpa membawa harta sepeser pun. Beliau melakukan semua itu agar bisa terbebas dari Mbak Lastri. Akhirnya, beliau pergi ke Panti Jompo untuk menghabiskan masa tuannya. Baginya, uang bukanlah segalanya.

b. Kemiskinan Moral

Dalam novel Tentang Кати karya Tere Liye terjadi kemiskinan moral. Tingkah laku yang dilakukan olah Mahasiswa di Jakarta menggambarkan bahwa miskinnya moral yang mereka miliki. Demo yang berubah menjadi amukan sangat berdampak negatif bagi pedagang maupun kios di Pasar Senen.

"Kekacauan besar terjadi di Jakarta seminggu lalu, saat Mahasiswa yang berdemo berubah menjadi amukan. Pasar Senen dibakar, asap tebal mengepul di Jakarta. Kerusuhan 
terjadi di mana-mana" (TK/1/249/Kms).

Pada data di atas diketahui bahwa kalimat yang digarisbawahi menjelaskan terjadi konflik sosial yang berupa kemiskinan moral yang tertuju pada Mahasiswa di Jakarta. Tingkah laku yang dilakukan Mahasiswa menggambarkan bahwa rendahnya moral yang dimilikinya. Tanpa mereka sadari, demo yang berupa amukan berdampak negatif bagi pedagang-pedagang maupun kios yang berada di Pasar Senen di Jakarta. Banyak kios yang hancur akibat amukan Mahasiswa. Salah satunya kios yang dimiliki oleh Sri Ningsih.

c. Kemiskinan Agama

Dalam novel Tentang Кати karya Tere Liye terjadi kemiskinan Agama. Perbuatan keji yang dilakukan oleh Mas Musoh dan Mbak Lastri mencerminkan bahwa miskinnya nilai-nilai yang berhubungan dengan agama. Berawal dari dengki alias iri hati membuat mereka beralih ke perbuatan negatif. Kutipan di bawah ini menjelaskan tentang kemiskinan agama yang dimiliki oleh Mas Musoh dan Mbak Lastri.

"Dan yang mengganggu Sri, sejak sore hingga subuh tinggal di rumah Mbak Lastri, tidak sekali pun Sri menyaksikan Mas Musoh dan Mbak Lastri shalat" (TK/1/186/Kms).

Pada data di atas diketahui bahwa kalimat yang digarisbawahi menjelaskan terjadi konflik sosial yang berupa kemiskinan moral yang tertuju pada Mas Musoh dan Mbak Lastri atau Sulastri. Sebelum menjadi seseorang yang keji, mereka adalah seorang ustaz dan ustazah yang sangat pintar. Berawal dari rasa iri karena Kiai Ma'sum menjodohkan anaknya yang bernama Nuraini dengan Arifin, mereka menjadi malas mengajar di Pesantren. Kedatangan Arifin menyebabkan putusnya silaturahmi. Mereka mengira bahwa Arifin akan menjadi ahli waris dari pemilik pesantren. Hasilnya, Mas Musoh dan Mbak Lastri berhenti berdakwah dan sangat membenci keluarga Kiai Ma'sum. Akhirnya, mereka menjadi manusia yang keji yang menentang agama, tidak pernah shalat, sukanya minum-minuman bir di pabrik gula, bahkan rela menghabisi nyawa orang yang tidak bersalah.

Menurut Soekanto (2014:319), kemiskinan dapat diartikan sebagai suatu keadaan, di mana seseorang tidak sanggup menjaga dirinya sendiri sesuai taraf kehidupan kelompok dan tidak mampu memanfaatkan tenaga mental dan fisiknya dalam kelompok tersebut. Kemiskinan yang terjadi pada novel tersebut antara lain: kemiskinan harta, kemiskinan moral, dan kemiskinan agama. Hal ini sesuai dengan teori Ralf Dahrendorf yang menyatakan bahwa kemiskinan termasuk konflik dalam peran sosial (intrapribadi). Kemiskinan harta menjadi simbol dari masyarakat yang serba kekurangan dari segi finansial atau ekonomi. Selanjutnya, kemiskinan moral dimiliki oleh seseorang yang tidak mengerti tentang tata krama yang berlaku dalam masyarakat sehingga sering melakukan perbuatan-perbuatan yang menyimpang. Terakhir adalah kemiskinan agama. Seseorang dikatakan miskin agama apabila dia tidak pernah mendekatkan diri kepada Sang Pencipta dan rela melakukan segala hal yang bertentangan dengan agama. Oleh karena itu, agama sangat berperan penting dalam kehidupan.
(2) Kejahatan 
Dalam novel Tentang Кати karya Tere Liye terjadi kejahatan yang dilakukan oleh Nusi Maratta kepada Sri Ningsih. Kejahatan tersebut berupa kekerasan, fisiknya disakiti, bahkan hatinya pun tersakiti. Kutipan di bawah ini menjelaskan tentang kejahatan yang dilakukan oleh Nusi Maratta kepada Sri Ningsih.

"Matamu ditaruh di mana?" Nusi Maratta meraih rotan panjang di atas meja.

Sri hendak melangkah mundur, tapi kakinya seperti berat digerakkan.

"Kamu kira harga bahan makanan murah? Gratis?"

Nusi memukul rotan, menghantam telak lengan Sri" (TK/2/104/Kjt).

Pada data di atas diketahui bahwa kalimat yang digarisbawahi menjelaskan terjadi konflik sosial yang berupa kejahatan terjadi pada Sri Ningsih. Enam bulan semenjak kepergian Nugroho, membuat Nusi Maratta marah besar. Seperti sekarang, saat Sri menumpahkan makanan dari mangkok ketika hendak membawanya ke meja makan. Sedikit sekali yang tumpah tapi membuat Nusi Maratta sangat marah. Menyuruh Sri mengepel seluruh lantai. Kemudian, memukulinya dan tidak memberi makan.

Soekanto

(2014:320)

menyatakan bahwa kejahatan merupakan suatu tindakan yang melanggar undang-undang atau ketentuan yang berlaku dan diakui secara legal. Secara kriminologi kejahatan merupkan suatu pola tingkah laku yang merugikan masyarakat. Kejahatan disebabkan karena kondisi-kondisi dan prosesproses sosial yang sama, yang menghasilkan perilaku-perilaku sosial lainnya. Konflik sosial yang berupa kejahatan ini paling banyak digambarkan dalam novel tersebut. Hal ini sesuai dengan teori Ralf Dahrendorf yang menyatakan bahwa kejahatan termasuk konflik antara kelompok-kelompok sosial (antarkeluarga). Dalam penelitian tersebut konflik antara kelompokkelompok sosial terjadi karena adanya perbedaan kepentingan dalam upaya mencukupi kebutuhan kelompok tersebut. Contoh konflik antara kelompok sosial dari keluarga Kiai Ma'sum dan keluarga Mas Musoh.

\section{(3) Disorganisasi Keluarga}

Disorganisasi keluarga yang berbentuk krisis keluarga ini terjadi pada Sri Ningsih. Di sini Hakan yang menjadi suami Sri Ningsih meninggal dunia akibat sakit demam. Hakan yang bertindak sebagai kepala keluarga meninggalkan Sri Ningsih. Kutipan tersebut dapat dilihat di bawah ini.

"Napas Hakan mulai tersengal, tubuhnya mengejang.

"Apa yang terjadi, Hakan? Ya Tuhan!"

Hakan menatap wajah istrinya untuk terakhir kali.

"Jangan Pergi, Hakan!! Aku mohon!" Sri berseru panik.

Mata Hakan menutup perlahan" (TK/3/409/Dkg).

Pada data di atas diketahui bahwa kalimat yang digarisbawahi menjelaskan terjadi konflik sosial yang berupa disorganisasi keluarga yang terjadi pada Sri Ningsih. Disorganisasi keluarga yang dialami oleh Sri Ningsih ini berbentuk krisis keluarga. Hakan yang bertindak sebagai kepala keluarga pergi meninggalkan rumah tangga karena meninggal dunia.

Menurut Soekanto (2014:324), disorganisasi keluarga adalah 
perpecahan keluarga sebagai suatu unit karena anggota-anggotanya gagal memenuhi kewajiban-kewajibannya yang sesuai dengan peranan sosialnya. Disorganisasi keluarga yang terjadi dalam penelitian ini disebabkan karena seorang yang bertindak sebagai kepala keluarga pergi meninggalkan keluarganya karena meninggal dunia. Hal ini sesuai dengan teori Ralf Dahrendorf yang menyatakan bahwa disorganisasi keluarga termasuk konflik dalam peran sosial (intrapribadi). Bentuk konflik ini merupakan suatu kondisi di mana seseorang mendapatkan kenyataan yang berlawannya dengan perannya dalam kehidupan nyata. Contoh dalam kasus ini adalah peran seorang istri yang menggantikan peran suami yang telah meninggalkan keluarganya.

\section{(4) Masalah Generasi Muda dalam Masyarakat Modern}

Dalam novel Tentang Кати karya Tere Liye terjadi konflik sosial yang berupa perebutan harta warisan yang dilakukan oleh Mas Musoh dan Mbak Lastri. Mereka berdua ingin menguasai madrasah yang dimiliki Kiai Ma'sum. Mereka juga merencanakan sesuatu untuk bisa merebutnya dan madrasah itu akan dijadikan sekolah baru. Dengan cara itu, mereka mengira bahwa hidupnya akan makmur. Hal itu dapat dilihat pada kutipan di bawah ini.

"Besok pagi, kita telah menguasai madrasah; kamu bisa kembali menjadi guru setelah kita mengubah madrasah itu menjadi sekolah baru. Kita akan menguasai seluruh harta madrasah, kita akan hidup makmur. Itulah rencana Mas Musoh, dia bisa mengambil-alih madrasah sialan itu dari Arifin" (TK/4/191/Mgm).
Pada data di atas diketahui bahwa kalimat yang digarisbawahi menjelaskan tokoh yang bernama Mas Musoh dan Mbak Lastri mempunyai niat jahat untuk menghancurkan pesantren yang dimiliki oleh Kiai Ma'sum. Hal itu dilakukan karena mereka ingin mengincar madrasah untuk dijadikan miliknya. Mereka tidak ingin madrasah yang dimiliki Kiai Ma'sum jatuh di tangan Arifin. Mereka mempunyai niat untuk membongkar madrasah menjadi sekolah baru agar bisa menjadi guru lagi. Tidak hanya itu saja, mereka berkeinginan untuk menguasai harta di madrasah agar bisa hidup dengan makmur.

Soekanto

$(2014: 325)$

menyatakan bahwa masalah generasi muda pada umumnya ditandai oleh dua ciri yang berlawanan, yakni keinginan untuk melawan (misalnya dalam bentuk radikalisme, delinkuensi, dan sebagainya) dan sikap yang apatis (misalnya penyesuaian yang membabi buta terhadap ukuran moral generasi tua). Sikap melawan mungkin disertai dengan suatu rasa takut bahwa masyarakat akan hancur karena perbuatan-perbuatan menyimpang. Sementara itu, sikap apatis biasanya disertai dengan rasa kecewa terhadap masyarakat. Banyak permasalahan yang ditemukan oleh peneliti. Salah satu bentuk masalah generasi muda yang terjadi yaitu dengki alias iri hati. Permasalah itu disebut sebagai penyakit yang paling ampuh, sehingga menyebabkan adanya percekcokan atau perselisihan. Hal ini sesuai dengan teori Ralf Dahrendorf yang menyatakan bahwa masalah generasi muda dalam masyarakat modern termasuk konflik dalam peran sosial (intrapribadi).

\section{(5) Peperangan}


Sosiologi menganggap peperangan sebagai suatu gejala yang disebabkan oleh berbagai faktor. Peperangan merupakan satu bentuk pertentangan dan juga suatu lembaga kemasyarakatan.

Peperangan merupakan bentuk pertentangan yang setiap kali diakhiri dengan suatu akomodasi.

Peperangan mengakibatkan disorganisasi dalam berbagai aspek kemasyarakatan. Dalam novel Tentang Кати terjadi konflik sosial yang berupa peperangan dapat dilihat pada kutipan-kutipan sebagai berikut.

"Pertikaian, gesekan, bahkan benturan mulai terjadi di berbagai daerah. Provokasi setiap hari dilakukan, kebencian terhadap agama terus digemakan, seolah semua kiai adalah orang jahat munafik. Siapa pun yang bicara agama, maka dia sok suci. Sri lambat laun memahami situasi tersebut, yakni ada kelompok tertentu yang berusaha menyerang agama" (TK/5/188/Ppg).

Pada data di atas diketahui bahwa kalimat yang digarisbawahi menjelaskan tentang peperangan di Jakarta. Peperangan tersebut dilakukan oleh kelompok Musoh. Sebelum pertingkaian berlangsung, mereka berhasil untuk menguasai Jakarta. Mereka membawa golok tajam yang digunakan untuk menghabisi tuan tanah, para kiai, dan militer. Mereka juga berencana untuk menyerang madrasah milik Kiai Ma'sum. Mereka akan menghabisi orang-orang yang berada di sana.

\section{Soekanto}

(2014:327)

menyatakan bahwa peperangan merupakan bentuk pertentangan yang setiap kali diakhiri dengan suatu akomodasi.

Peperangan mengakibatkan disorganisasi dalam berbagai aspek kemasyarakatan. Dalam penelitian tersebut terdapat tujuh data yang berupa peperangan dalam novel Tentang Кати karya Tere Liye. Peperangan yang terjadi pada penelitian tersebut terjadi karena amukan mahasiswa dan paling besar disebabkan karena faktor internal. Masalah peperangan tersebut berbeda dengan masalah sosial lainnya karena menyangkut beberapa masyarakat sekaligus, sehingga memerlukan kerja sama internasional yang hingga kini belum berkembang dengan baik. Hal ini sesuai dengan teori Ralf Dahrendorf yang menyatakan bahwa peperangan termasuk konflik antara kelompok-kelompok sosial. Dalam penelitian tersebut konflik antara kelompok-kelompok sosial terjadi karena adanya keinginan untuk mendapatkan penguasaan madrasah yang dimiliki oleh Kiai Ma'sum. Akhirnya pihak lawan memilih untuk mengambil alih dengan cara paksa dan perang yang berakhir tragis.

\section{(6) Pelanggaran terhadap Norma-norma Masyarakat}

Pelanggaran terhadap normanorma masyarakat dilakukan oleh beberapa tokoh. Pelanggaran yang berupa pelacuran terjadi pada Sulastri karena dia rela menjual harga dirinya demi uang. Selanjutnya, delinkuensi anak-anak yang terjadi dalam novel Tentang Кати karya Tere Liye meliputi pencurian, penganiyaan, pelanggaran susila, dan penggunaan obat-obatan, dan pelanggaran karena minum-minuman keras seperti bir. Konflik sosial yang berupa pelanggaran terhadap norma-norma masyarakat dapat dilihat pada kutipan-kutipan sebagai berikut.

a. Pelacuran

Pelacuran dapat diartikan sebagai suatu pekerjaan yang bersifat menyerahkan diri kepada umum 
untuk melakukan perbuatanperbuatan seksual dengan mendapat uang. Apakah pelacuran merupakan masalah sosial disini, yang penting adalah bahwa soal tersebut mempunyai pengaruh besar terhadap moral. Pelacur dijumpai di kota Jakarta misalnya (dan juga di kotakota besar lainnya) dikatakan bukan masalah sosial utama karena pengaruhnya terhadap ekonomi negara, stabilitas politik, kebudayaan bangsa atau kekuatan nasional kecil sekali.

"Untuk seorang Sulastri yang menghalalkan segala cara, tidak sulit menaklukkan kota Jakarta. Dia cukup menggoda seorang pejabat pemerintah, menjual wajah dan tubuhnya yang masih muda, menjadi istri simpanan" (TK/6/501/Pnm).

Pada data di atas diketahui bahwa kalimat yang digarisbawahi menjelaskan tentang seorang Sulastri menghalalkan berbagai cara untuk bisa memiliki banyak uang. Dia rela menjual harga diri serta menjadi wanita simpanan oleh seorang pengusaha besar. Perbuatan yang dilakukan oleh Sulastri inilah yang dinamakan pelacuran. Rela menyerakan dirinya kepada orang lain untuk melakukan perbuatanperbuatan seksual dengan mendapat uang. Demi kelancaran perekonomian, Sulastri rela melakukan hal-hal yang dilarang. Pelanggaran yang dilakukan Sulastri menjelaskan bahwa betapa buruknya moral yang dia miliki.

b. Delinkuensi Anak-anak

Delinkuensi anak-anak di Indonesia meningkat pada tahun 1956 dan 1958 dan juga pada 1968-1969, yang sering ditengarai dalam pernyataan-pernyataan resmi pejabat, maupun petugas-petugas penegak hukum. Delinkuensi anak-anak meliputi pencurian, perampokan, pencopetan, penganiyaan, pelanggaran susila, penggunaan obatobatan perangsang, dan mengendarai mobil (atau kendaraan bermotor lainnya) tanpa mengindahkan normanorma lalu lintas. Dalam novel Tentang Kamu terjadi delinkuensi anak-anak yang berupa pencurian, penganiayaan, pelanggaran susila, dan penggunaan obat-obatan terlarang.

"Cucunya yang pengangguran, bejat, pernah masuk penjara dua kali karena memerkosa remaja" (TK/6/442/Pnm).

Pada data di atas diketahui bahwa kalimat yang digarisbawahi menjelaskan tentang pelanggaran susila terjadi pada seorang cucu pengusaha besar Jerman. Tidak semua orang terpandang mempunyai perilaku yang baik. Hal itu digambarkan jelas oleh seorang cucu pengusaha tersebut. Seorang cucu yang tidak bekerja menjadi pengangguran, mempunyai moral yang rusak, melakukan pemerkosaan kepada remaja sehingga membuatnya tertahan di balik jeruji besi. Sungguh pelanggaran yang dilakukan oleh seorang cucu ini begitu banyak. Berbagai pelanggaran dia lakukan. Tidak tahu apa penyebab cucu ini rela melakukan hal-hal yang bertentangan dengan norma-norma yang berlaku di masyarakat.

Konflik sosial yang terakhir yakni pelanggaran terhadap normanorma masyarakat. Peneliti menggunakan teori konflik sosial menurut Soekanto (2014:328-329). Dalam penelitian tersebut terdapat pelanggaran yang berupa pelacuran, delinkuensi anak-anak, dan alkoholisme. Delinkuensi anak-anak yang terjadi dalam novel tersebut 
antara lain: pencurian, penganiayaan, pelanggaran susila, dan penggunaan obat-obatan. Konflik yang terjadi pada novel ini menggambarkan bahwa peristiwa inilah yang juga terjadi pada kehidupan masyarakat sekarang. Hal ini sesuai dengan teori Ralf Dahrendorf yang menyatakan bahwa pelanggaran terhadap normanorma masyarakat termasuk konflik dalam peran sosial (intrapribadi). Oleh karena itu, faktor internal sangat berpengaruh terhadap segala hal.

\section{SIMPULAN}

Berdasarkan hasil penelitian dan pembahasan mengenai konflik sosial dalam novel Tentang Kamukarya Tere Liye pada bab sebelumnya terdapat beberapa hal yang dapat diambil kesimpulan sebagai berikut. Pertama, dalam novel Tentang Кати karya Tere Liye ditemukan adanya konflik sosial antara lain: (a) kemiskinan yang meliputi kemiskinan harta, kemiskinan moral, dan kemiskinan agama, (b) kejahatan yang berupa penindasan, penganiayaan, dan pembunuhan, (c) disorganisasi keluarga yang berbentuk krisis keluarga (kepala keluarga meninggalkan rumah tangga karena meninggal dunia dan peperangan), (d) masalah generasi muda dalam masyarakat modern, (e) peperangan yang berupa perkelahian, dan (f) pelanggaran terhadap norma-norma masyarakat yang berupa pelacuran dan delinkuensi anak-anak (pencurian, penganiyaan, pelanggaran susila, penggunaan obat-obatan, dan alkoholisme).

\section{DAFTAR PUSTAKA}

Asriani, Lia. 2016. "Masalah-Masalah Sosial dalam Novel Dari Subuh Hingga Malam: Perjalanan Seorang Putra Minang Mencari Jalan Kebenaran Karya Abdul Wadud Karim Amrullah".Dalam Jurnal

Bastra, Vol. 1 (1): 1-4.

Fauzia. 2013. "Masalah Sosial dalam Novel Pulang Karya Leila S. Chudori”. Dalam Jurnal Bastra, Vol. 1 (1): 1-9.

Liye, Tere. 2016. Tentang Кати. Jakarta: Republika Penerbit.

Ratna, Nyoman Kutha. 2003. Paradigma Sosiologi Sastra. Denpasar: Pustaka Pelajar.

Ratna, Nyoman Kutha. 2006. Teori, Metode, dan Teknik Penelitian Sastra. Yogyakarta: Pustaka Pelajar.

Santoso,Wijaya Heru dan Wahyuningtyas. 2010.

Pengantar Apresiasi Prosa.

Surakarta: Yuma Pustaka.

Saraswati, Ekarini. 2003. Sosiologi Sastra: Sebuah Pengantar Awal. Malang: UMM Press.

Soekanto, Soerjono dan Budi Sulistyowati. 2014. Sosiologi Suatu Pengantar. Jakarta: PT Raja Grafindo Persada.

Zahroh, Ubaidah. 2015. Problem Sosial dalam Novel Badar Karya Zaky Yamani Tinjauan Sosiologi Sastra dan Relevansinya sebagai Bahan Ajar Sastra di SMA.

http://eprints.ums.ac.id/36407/1 /NASKAH\%20PUBLIKASI.pd f, diunduh 19 Desember 2017 pukul 10.35 . 